\title{
Brexit and the
}

\section{Consequences for Commercial and Financial Relations between the EU and the UK}

\author{
by Professor Dr Matthias Lehmann (University of Bonn) and \\ Professor Dr Dirk Zetzsche (University of Luxembourg)
}

The UK's withdrawal from the European Union will have - and already has - a dramatic impact on the political, legal and economic landscape, both in Britain and on the continent. This contribution takes a closer look at the effects on individual relationships and businesses. Against the background of the possible scenarios (British accession to the European Economic Area (EEA), bilateral trade agreement with the EU, or 'hard' exit with third-country status), it scrutinizes Brexit's consequences in five areas: contract law, the law of non-contractual obligations, corporate law, financial law, and international litigation. With regard to contract law, it examines the effects on the determination of the applicable law and on substantive contract law, in particular the possibility to terminate contractual agreements. Concerning non-contractual obligations, it deals with the conflict rules applicable to torts, which may change. In the context of corporate law, the focus is on the status of companies organized under English law that are domiciled in Member States, as well as on the fate of European public companies headquartered in Britain. Insolvency matters will also be discussed. The part on financial law analyses the options for EU market access available to English banks, asset and fund managers as well as insurance companies in light of the passport granted to EEA firms and the equivalence requirements for third-country firms. As regards international litigation, the discussion turns on the post-Brexit determination of the competent court as well as the recognition and enforcement of British judgements in the EU.

On 23 June 2016, the British people voted to leave the European Union. The outcome of the referendum has no direct legal effect, neither as a matter of UK law nor in the relation with other states. However, the United Kingdom is likely to invoke Article 50 of the Treaty on the European Union (TEU) in the foreseeable future, which will trigger exit negotiations with the remaining 27 Member States. The EU treaties will cease to apply to the UK after the entry into force of a withdrawal agreement, or failing such agreement after a period of two years unless an extension is granted by a unanimous (!) decision of all Member States. ${ }^{1}$ This article examines the consequences of the UK's exit from the EU in the area of commerce and finance.

\footnotetext{
${ }^{1}$ See Art 50(2) TEU.
} 


\section{Scenarios}

The impact of Brexit depends on the terms of the withdrawal agreement under Art. 50 TEU. It is rather likely that this will not remain the only treaty to be agreed upon between the UK and the EU but that one or several others will be necessary to determine their future relationship. ${ }^{2}$ There are of course myriad ways in which the relations between both partners could potentially be structured, depending on the outcome of the negotiations. Three basic scenarios stand out, however.

\section{A. Accession to the European Economic Area}

A first possibility is that the UK joins the likes of Norway, Liechtenstein and Iceland to become a member of the European Economic Area (EEA). ${ }^{3}$ The EEA, which was established in 1994, is not a customs union, so the UK would be free to negotiate its own trade deals with other countries and thus fulfil one of the objectives pursued by the Leave campaign. At the same time, the four fundamental freedoms (freedom of goods, of services, of persons and of capital) would continue to apply to the UK. ${ }^{4}$ This solution would guarantee British companies and undertakings unfettered access to the Internal Market. The UK would however be bound by all acts of the EU that are mentioned in the Agreement or referred to by the EEA Joint Committee..$^{5}$ It would therefore have to transpose all directives and apply all regulations of the EU in the field of business and finance without being able to influence their content because of its absence at the negotiating table in Brussels. Such 'diplomacy by fax' will be difficult to sell to the British public as an improvement over the current situation. An even more bitter pill to swallow is that workers would enjoy the same freedom of movement as they do today. This is hardly the result that those in favour of leaving the EU have had in mind.

The UK could however join the EEA under special conditions, and try to obtain what is sometimes called an 'EEA minus' state. In particular, it could strive to bargain

\footnotetext{
2 It has therefore been suggested that the withdrawal agreement and a treaty on future trading relations should be negotiated in parallel, see House of Lords, The Process of Withdrawing from the European Union, 2016, 11th Report of Session 2015-16, HL Paper 138, 4 May 2016, p. 10, margin no. 31, quoting Derrick Wyatt.

${ }^{3}$ Agreement on the European Economic Area of 17 March 1993, OJEU No L 1, 3.1.1994, p. 3. The EEA Agreement entered into force on 1 January 1994.

${ }^{4}$ See Art 1(2) EEA Agreement.

${ }^{5}$ Art 7 EEA Agreement.
} 
for an upper limit of the number of migrants coming from other EU Member States to its territory. Such conditionality is not unheard of: The increase in number of foreigners taking up residence in Liechtenstein is limited to a certain percentage (1.75\%) per year. ${ }^{6}$ This limit is however due to the particularities of a very small country. We doubt that a similar restriction can be obtained by the UK. Furthermore, the cap provides for a much higher immigration level than that which the British people seems to be willing to accept. It is therefore unsure whether a clause of this sort would satisfy British demands.

\section{B. Bilateral Agreement}

The second option for the UK would be a bilateral free trade agreement with the European Union. As a model, one could look to Switzerland. It has concluded over 100 sector-based agreements with the EU. ${ }^{7}$ Yet such an issue-by-issue negotiation is drawn out, and it is doubtful whether it would be political feasible. The Council has publicly announced its disinclination to negotiate further bilateral agreements with Switzerland. ${ }^{8} \mathrm{~A}$ bilateral approach for the EU - UK relations would run counter to that statement.

Another model to follow would be that of Canada, which has recently signed the CETA Agreement with the EU. ${ }^{9}$ CETA has yet to be ratified by the Member States and not entered into force. If it is adopted, it will bring great progress in the protection of investments and in the free trade of goods, particularly by dismantling so-called Technical Barriers to Trade. CETA is rather weak, though, when it comes to trade in services. It only secures the passive freedom of service, i.e. the right of persons located in the territory of one contracting state to purchase a financial service from a cross-border supplier of the other contracting state, but does not guarantee active freedom of service, i.e. the permission of suppliers of one contracting state to do

\footnotetext{
${ }^{6}$ See Annex VIII EEA Agreement.

7 This number includes amendments and updates of original agreements. The precise number depends of the notion 'agreement', see M Vahl and N Grolimund, Integration Without Membership: Switzerland's Bilateral Agreements with the European Union (CEPS 2006) 22.

${ }^{8}$ Council of the European Union, Conclusions on EU Relations with EFTA Countries, 14.12.2010, Council document 5101/13, sub no. 6 ("In full respect of the Swiss sovereignty and choices, the Council has come to the conclusion that while the present system of bilateral agreements has worked well in the past, the challenge of the coming years will be to go beyond this complex system, which is creating legal uncertainty and has become unwieldy to manage and has clearly reached its limits.")

${ }^{9}$ Comprehensive Economic and Trade Agreement (CETA) between Canada, of the one part, and the European Union and Its Member States (reprinted in COM(2016) 443 final, Annex I).
} 
business and solicit in the territory of the other contracting state. ${ }^{10}$ CETA furthermore provides a 'prudential carve-out' for all regulatory measures. ${ }^{11}$ If this model were to be followed, UK financial services firms serving EU customers would need to fully comply with EU rules. In turn, they would need to set up EU branches is if they were entirely unrelated to the EU.

\section{Third Country-Status}

As a third option, it is also possible that the UK and the EU will not, or at least not immediately coinciding with Brexit, reach any agreement on their future commercial relations. The UK would then have the same status as any third country in relation to the EU, and so would the EU Member States in relation to the UK. Imports and exports would fall under WTO law, namely GATT and GATS. ${ }^{12}$ The principles of most favoured nation and of national treatment would secure a minimum of free trade in goods. Technical barriers, such as differences in product regulation, would however remain. This would force firms to comply with dual standards and lead to additional paperwork, e.g. for certifying compatibility with security requirements in the export destination. Even more important are obstacles to the provision of services. The GATS accords market access and national treatment only where the contracting states have undertaken specific commitments. ${ }^{13}$

Specific GATS commitments do not exist between the UK and the EU Member States. They were thought to be unnecessary at the time of the conclusion of GATS because the UK was a Member of the then EC. These commitments would thus have to be first negotiated before British firms can offer their services to clients on the continent, and vice versa. Even then, British firms would be subject to EU rules on third countries which could, for some regulated sectors, amount to the requirement to fully comply with EU law.

\footnotetext{
${ }^{10}$ Art. 13.7(6) ibid. The weakness of the obligations of the Parties is compounded by the fact that they retain the right to define the notion 'doing business' and 'solicitation', see ibid.

${ }_{11}$ Art. 13.16 ibid.

12 Both the EU and the UK have signed the WTO Agreements in Marrakesh in 1994. The UK will therefore continue to be bound by the revised GATT and the GATS. Some authors argue, though, that a renegotiation of the UK's membership is needed as it will not be able to fulfil the obligations undertaken by the EU on its behalf, see Markus W Gehring, 'EU Law Analysis: Brexit and EU-UK Trade Relations with Third States' <http://eulawanalysis.blogspot.com/2016/03/brexit-and-eu-uk-traderelations-with.html> accessed 12 August 2016.

${ }^{13}$ Art XVI and XVII GATS.
} 


\section{A Bespoke Relation}

It is unlikely that the future relations between the EU and the UK will simply be a copycat of an arrangement between the EU and another state. The British Prime Minister Theresa May has made it known that she is aiming for a solution that departs from existing models. ${ }^{14}$ It is not unlikely that the importance of maintaining mutually beneficial trading relations will inspire both partners to forge a tailor-made compromise. However, any outcome will still fall under one of the three main scenarios: it can either be accession to the EEA, i.e. a multilateral solution, a bilateral agreement, or no deal at all.

Game theory is useful to throw light on the path that the negotiations can take. ${ }^{15}$ At first blush, the situation seems to resemble that of a typical prisoner's dilemma, in which both sides are better off if they cooperate. However, the payoffs for the EU are greatly reduced because any attractive bargain for the UK may encourage other Member States to head for the exit door as well. The EU has thus less reasons to be forthcoming to the UK than a player in a typical prisoner's dilemma. Moreover, the EU can hardly be stylized as a single player because it is driven by the - very diverse preferences of the 27 remaining Member States. As these preferences and those of the UK are constantly changing with the evolving political situation, one can imagine that the separation agreement will not be the final say but rather the start of new and repeated attempts at modelling their relationship.

There is not much sense in trying to gaze into a crystal ball. The only certainty for now is that it is impossible to predict the exact outcome of the negotiation process. In the following, the consequences of Brexit must therefore be evaluated against the backdrop of the current legal situation. Along the way, possibilities for special

\footnotetext{
14 The Prime Minister said: 'We need to find a solution that addresses the concerns of the British people about free movement, while getting the best possible deal on trade in goods and services. We should be driven by what is in the best interests of the UK and what is going to work for the European Union, not by the models that already exist.', see 'PM and Slovakian Prime Minister Fico Statements in Bratislava: 28 July 2016 - Speeches - GOV.UK' <https://www.gov.uk/government/speeches/pmstatement-after-meeting-slovakian-prime-minister-fico-in-bratislava-28-july-2016> accessed 12 August 2016.

${ }^{15}$ Game theory has already been used to study the interaction between the EU and the UK before the referendum, see Maneesha, Nishant Vijay and Apoorva Singh, 'To Develop a Game Theory Model Analyzing the Negotiations between Britain and European Union', Proceedings of the Fourth Middle East Conference on Global Business, Economics, Finance and Social Sciences (ME16 Dubai May Conference),13-15 May, 2016, available at http://globalbizresearch.org/Dubai_Conference_2016_May/docs/1.\%20Global\%20Business,\%20Econ omics\%20\&\%20Sustainability/D633.pdf (last accessed 13 August 2016).
} 
arrangements that deviate from existing models will be discussed. The analysis will therefore yield not so much a prediction of what is to be expected than an outline of what needs to be done and agreed on specially. We will first look at the consequences for contractual relations (II), then at non-contractual relationships, in particular at torts (III). After that, we will deal with company law - including insolvency law - (IV), financial law $(\mathrm{V})$, and finally with dispute resolution (VI).

\section{Brexit's Impact on Contract Law}

The loss of the UK's status as an EU Member State could impact on existing contracts between private actors, both juridical or natural persons, on two different levels: It could either change the selection of the applicable law, or have consequence on the level of substantive contract law.

\section{A. Consequences for Conflict of Laws}

Legal certainty in contractual relations would be seriously affected if the legal system that applies to private agreements would change as a result of Brexit. On both sides of the Channel, courts so far determine the law applicable to contracts via the rules of the Rome I Regulation. ${ }^{16}$ After the UK has quit the Union, this regulation will cease to apply in British courts. The Rome I Regulation has however a forerunner with a very similar content, i.e. the Rome Convention. ${ }^{17}$ The question arises as to whether this convention will revive and be of continued relevance post Brexit. Two problems have to be distinguished in this regard.

The first problem is whether a non-EU Member State can be party to the Rome Convention. When it was signed in 1980, the treaty was open only to Member States of the then European Economic Community (EEC). Its goal was to favour the creation of the Internal Market by harmonizing conflict rules for contracts. ${ }^{18}$ The strong

\footnotetext{
${ }^{16}$ Regulation (EC) No 593/2008 of 17 June 2008 on the law applicable to contractual obligations (Rome I), OJ L $177 / 6$.

17 Convention 80/934/EEC, Convention on the law applicable to contractual obligations, concluded at Rome on 19 June 1980, [1980] OJ L266/1.

${ }^{18}$ See the opening address by T Vogelaar, Director-General for the Internal Market and Approximation of Legislation at the Commission, at the meeting of government experts on 26 to 28 February 1969 , cited by M Giuliano and P Lagarde, Report on the Convention on the law applicable to contractual obligations, [1980] OJ C 282/4.
} 
connection to the EEC can still be witnessed in the Convention's Preamble, which introduces the signatories as the 'High Contracting Parties to the Treaty establishing the European Economic Community'. It can therefore be reasonably argued that the Convention cannot have any effect with regard to a non-Member State. On the other hand, one must not neglect the fact that the Member States consciously chose not to use the legislative machinery of the EEC, but instead adopted a convention. The Rome Convention has been signed and ratified like any ordinary treaty under general public international law. Though it was politically inspired by the Treaty of Rome concluded in 1957, it has an independent legal nature and is not part of EU law. This view is buttressed by the fact that the signatory States have thought it necessary to conclude a separate Protocol to allow the ECJ to interpret the Convention, ${ }^{19}$ which would not have been necessary had they considered the Convention to be primary or seconary European law. Furthermore, the Convention does not contain any condition requiring continued membership of its signatories in the EEC or its successor organisations. It is quite plausible that the drafters might not have foreseen the possibility of a Member State exiting the Community, given that they did not expressly provide for this right in EEC primary law at the time of signing the Convention. However, any lacuna in the Rome Convention has to be filled by applying the Vienna Convention on the Law of Treaties, which governs the interpretation of all international agreements. As a consequence of circumstances that were not foreseen at the time of conclusion of the treaty, the Vienna Convention only provides States with the right to terminate a treaty or to withdraw from it, not for an automatic end. ${ }^{20}$ Moreover, this right exist only where "the effect of the change is radically to transform the extent of obligations still to be performed under the treaty". ${ }^{21}$ Arguably, the remaining Member States and the UK may still perform the obligations under the Rome Convention after Britain's departure from the EU, namely to apply the law designated by the Convention's rules.

The second question is whether the Rome Convention is still in force or whether it has been terminated as a result of the adoption of the Rome I Regulation. For the latter view, one could refer to Art 24(1) of the Rome I Regulation, according to which

\footnotetext{
${ }^{19}$ First Protocol on the interpretation of the 1980 Rome Convention by the Court of Justice, consolidated version in [1998] OJ C 27/47.

20 Vienna Convention on the Law of Treaties, UNTS vol. 1155, I-18232, concluded at Vienna on 23 May 1969, Art 62(1).

${ }^{21} \mathrm{Id}$, Art 62(1)(b).
} 
the Regulation "replaces" the Rome Convention. ${ }^{22}$ The same provision adds that the Convention continues to apply to those territories of Member States which fall within its territorial scope but are not covered by the Regulation. Those are mainly British, Dutch and French overseas territories that are not part of the EU. ${ }^{23}$ It has been argued that the reference to "Member States" in Article 24 Rome I would exclude the continued application of the Convention to non-Member States. ${ }^{24}$ Yet the provision as such is incapable to change the scope of an act under public international law to which non-Member States are a party. Article 24 Rome I also does not mention Denmark, which refused to take part in EU judicial cooperation and therefore continues to be bound by the Rome Convention. ${ }^{25}$ All that Article 24 Rome I shows is that the Convention is not completely discarded, but continues to exist.

The better view is therefore that the Rome Convention still exists and will again be applicable to the relation between the UK and other signatory States once Brexit becomes a reality. ${ }^{26}$ The only Member State not bound by the Rome Convention is Croatia, which became an EU Member only in 2013, five years after the adoption of the Rome I Regulation. This does not matter, however, as the Convention establishes uniform rules - a 'loi uniforme' - of conflict of laws ${ }^{27}$ which continue to bind the UK. There will thus be no going back to the previously governing English rules of conflict of laws, which were not substantially different from the rules of the 1980 Rome Convention. ${ }^{28}$ Legal certainty with regard to the law applicable to contracts will therefore in general be maintained.

\footnotetext{
22 In this sense B Hess, 'Back to the Past: BREXIT und das europäische Internationale Privat- und Verfahrensrecht, 36 (2016) Praxis des Internationalen Privat- und Verfahrensrechts (IPRax) 409, 417. ${ }^{23}$ See the list in Annex II of the TFEU.

24 In this sense B Hess, 'Back to the Past: BREXIT und das europäische Internationale Privat- und Verfahrensrecht, 36 (2016) IPRax 409, 417.

25 See W-H Roth, 'Maßgebliche Kollisionsnormen im deutsch-dänischen Rechtsverkehr', 35 (2015) IPRax 222, 224-225. On the special position of Denmark, see Protocol 22 TFEU and Recital 46 Rome I Regulation.

${ }^{26}$ In the same sense, A Dickinson, 'Back to the Future: The UK's EU Exit and the Conflict of Laws', (2016) Journal of Private International Law 195, 204; J Ungerer, 'Brexit von Brüssel und den anderen EU-Verordnungen zum Internationalen Zivilverfahrens- und Privatrecht' (2016) Zeitschrift für das Privatrecht der Europäischen Union [forthcoming special edition]; E Lein, 'Unchartered Territory? A Few Thoughts on Private International Law Post-Brexit', 18 (2016) Yearbook of Private Interntional Law [forthcoming].

27 See Art 2 Rome Convention.

${ }^{28}$ See Adrian Briggs, The Conflict of Laws (Paul Craig ed, OUP Oxford 2013) 259 et seq. 262; Lawrence Collins et al. (ed), Dicey and Morris on the Conflict of Laws, vol 2 (13th ed, Sweet \& Maxwell 2000), para 32-019.
} 
There are however slight divergences between the Rome Convention and the Rome I Regulation. For example, the Rome Convention does not contain any of the Rome I rules about insurance contracts. ${ }^{29}$ Both texts also diverge regarding the treatment of foreign overriding mandatory rules. ${ }^{30}$ But there are also details to consider. One of these details pertains to Article 6(4) lit. d Rome I, which makes sure that all contractual ${ }^{31}$ relationships stemming from the issuance of, or public bids of, securities as well as collective investment schemes are governed by the same law (typically the law of the issuer, or fund manager, respectively), regardless of whether investors are consumers pursuant to Article 6(1) Rome I or not. In a similar vein, Article 6(4) lit. e Rome I subjects all contracts concluded within multilateral trading systems to the laws of one jurisdiction. These rules were added to the rules of the Rome Convention in order to ensure the uniformity of the legal regime applying to instruments such as shares or bonds, to takeover bids and to transactions on exchanges. ${ }^{32}$

The UK is well advised to remedy any divergence with Rome I by a provision in the withdrawal agreement or by a separate treaty clarifying that British courts will continue to apply the Rome I Regulation. Since both sides benefitted from the harmonization of conflicts rules, we do not deem the area politically sensitive; such an agreement is thus likely. It would, however, create problems with regard to the ECJ's jurisdiction (see infra part III).

\section{B. Consequences for Substantive Contract Law}

The implications of Brexit may also be felt when it comes to the rights and obligations arising out of private agreements. The fact that the UK is no longer an EU Member State may be a sufficient ground to terminate a contract. The precise consequences depend, of course, on the applicable rules.

\footnotetext{
29 See Art 7 Rome I Regulation. According to Article 1(3) Rome Convention, most insurance contracts fall outside of the Convention's scope.

${ }^{30}$ See Art 9(3) Rome I Regulation versus Art 7(2) Rome Convention.

${ }^{31}$ Some of the financial relationships may be governed by company, or trust law, respectively to which Rome I does not apply, cf. Art 1(2) lit. f, h Rome I.

${ }^{32}$ See F Garcimartín-Alférez, 'The Rome I Regulation: Exceptions to the Rule on Consumer Contracts and Financial Instruments', 4 (2009) Journal of Private International Law 141, 145; F GarcimartínAlférez, 'New Issues in the Rome I Regulation: The Special Provisions on Financial Markets Contracts', 10 (2008) Yearbook of Private international Law 245, 251. Not every aspect of these provisions is indispensible, though, see M Lehmann, 'Financial Instruments', in: F Ferrrari \& S Leible (eds.), The Law Applicable to Contractual Obligations in Europe (Sellier, Munich 2009), p. 85, 92 et seq.
} 
Under English law, both parties can be wholly discharged of their contractual obligations under the doctrine of frustration. ${ }^{33}$ Its conditions are however conceived very narrowly: It applies only where a supervening event either renders the performance of an obligation impossible or deprives it of all interest to both parties. ${ }^{34}$ Such situations will arise rarely. A hypothetical example involves an English law firm that advises a client regarding EU subsidies for an investment in the UK. As these subsidies will no longer be available after Brexit, the service promised will become pointless. But importantly, the doctrine of frustration does not apply where the performance of a contract has merely become more difficult or expensive. Thus, a contract is for example not frustrated by the fact that a UK bank has lost its EU passport and can only perform its obligation via a subsidiary or branch that it must first establish within the EU. Many long-term agreements under English law contain hardship or force majeure clauses. ${ }^{35}$ They could cover Brexit, but this depends on their precise wording.

Continental laws are often more receptive to the idea that a change of external circumstances may necessitate a modification of the obligations of parties to a contract. German law provides for the right to renegotiate or terminate a contract in case of a fundamental change of circumstances on which both parties have based their agreement. ${ }^{36}$ The Italian Codice civile allows the adaption or termination of a contract where supervening circumstances have rendered the performance of obligations by either party excessively onerous. ${ }^{37}$ The Spanish Supreme Court comes to a similar conclusion by assuming the existence of a tacit clausula rebus sic stantibus

\footnotetext{
${ }^{33}$ H. G Beale et al. (ed), Chitty on Contracts., vol 1, 30th edn (Sweet \& Maxwell 2008) para 23-071; E McKendrick 'Frustration, Remedies and Re-appraisal' in E McKendrick (ed), Force Majeure and Frustration of Contract (2 ed, Lloyd's of London Press 1995) 238; E McKendrick, Contract Law (11 ed, Palgrave Macmillan 2015) para 14.8.

${ }^{34}$ See e.g. Nicholl and Knight $v$ Ashton, Eldridge \& Co [1901] 2 KB 126, 132 et. seq.; Krell v Henry [1903] 2 KB 740, 748; Herne Bay Steam Boat v Hutton [1903] 2 KB 683, 689 et seq.; For the proposition that mere difficulties or increase in the expense of performance do not satisfy the conditions of frustration, see e.g. Davis Contractors v Fareham UDC [1956] AC 696, 713 et seq.; Tsakiroglou \& Co Ltd v Noblee Thorl GmbH [1962] AC 93, 115.

${ }^{35}$ E McKendrick, Force Majeure and Frustration of Contract (n 34) 7; H. G Beale et al. (n 34) para 23003.

${ }^{36}$ See sec. 313 German Civil Code (Bürgerliches Gesetzbuch - BGB). On the potential application of this provision in case of a withdrawal of one Member State from the Eurozone, see Peter Kindler, 'Währungsumstellung, Vertragskontinuität und Vertragsgestaltung - Denkanstöße zu den Auswirkungen eines Ausscheidens einzelner EU-Mitgliedstaaten aus dem Euro', [2012] Neue Juristische Wochenschrift 1617, 1620.

${ }^{37}$ Art 1467 Italian Codice civile.
} 
in the contract. ${ }^{38}$ While France has implemented a right to renegotiate or even dissolve of contracts under a hardship doctrine very recently, ${ }^{39} \mathrm{it}$ is noteworthy that this doctrine applies to contracts only concluded at or after 1 October 2016. At this point in time, however, the Brexit is no longer 'unforeseeable', thus it does not prompt the right to renegotiate or terminate the contract. Brexit may however incentivize courts in EU/EEA countries to develop a hardship doctrine outside of their civil codes and apply it retroactively to contracts entered into before the referendum of 23 June 2016. In doing so, these courts may be looking at the examples of Germany, Spain or other countries that have adopted the doctrine without a clear legislative basis.

Whether Brexit amounts to a fundamental change of circumstances that significantly alters the balance in the performance of contractual duties very much hinges on the specifics of the contract. In the aforementioned example of a bank losing its passport, the performance of the contract will become excessively onerous where the bank has only one client in the respective Member State, but arguably not so where the bank has contracted with a large number of clients who it could serve by means of establishing a new subsidiary or branch under the EU's third country rules.

With regard to employment contracts, the UK's exit from the EU may constitute a sufficient ground for terminating obligations. This will be true where the task fulfilled by the employee is no longer required. A case in point is the employment relationship with janitors or cleaning personnel for European Union bodies and agencies in London, such as the European Banking Authority (EBA), the European Medicines Agency (EMA) or the European Investment Bank (EIB). The essential staff of these agencies will continue to be employed but forced to move to a remaining Member State. For other cases, the legal situation is not so clear. A British airline that has lost the licence to perform intra-EU flights might for instance dismiss flight personnel, but only where their services cannot be used on other routes. Everything depends on the applicable law and the individual circumstances. The only certainty is that a certain nationality, whether British or that of a remaining Member State, should as such not be a ground for dismissal.

\footnotetext{
38 See Spanish Tribunal Supremo, judgment of 17 January 2013, ROJ STS 1013, 2013. For a discussion, see LM Martínez Velencoso, 'National Courts: How Can They Keep Track?', in: M Lehmann (ed.), Common European Sales Law Meets Reality (Sellier, Munich 2014), p. 99, 110-112.

39 See Art 1195 French Code Civil. Other civil law jurisdictions, such as Belgium or Luxembourg, could follow suit.
} 
To sum up, Brexit's consequences on the contract's substantive regime depends on (a) the applicable legal regime and (b) the factual question as to which extent it renders the performance of the contractual obligations impossible or more onerous.

Equally important will be the influence of Brexit on the development of contract law doctrine in the EU. English law was of particular importance for the nascent discipline of European private law, which is mostly conceived as a mixture of EU rules and comparative Member State law. ${ }^{40}$ English law has often served as a counter model to the more homogenous rules of countries following the continental tradition. It has thereby served as a gateway for the introduction of common law inspired solutions into the process of European legal harmonisation. ${ }^{41}$ With Ireland as the only remaining pure common law country in the EU, and Malta as a mixed sytems, this influence will now be greatly diminished. One may hope - or fret - that EU law will become more continental, and British law will return to its old roots. A new divide of private law may open up across the Channel.

\section{Brexit's Impact on the Law Applicable to Torts and Other Non-Contractual Obligations}

So far, British courts have had to determine the law governing non-contractual obligations in accordance with the Rome II Regulation. ${ }^{42}$ The category 'noncontractual obligations' encompasses e.g. unjust enrichment, negotiorum gestio, and pre-contractual liability (culpa in contrahendo). ${ }^{43}$ The Rome II Regulation provides dedicated conflict rules for each of those institutions. Because of the Regulation's principle of universal application, ${ }^{44}$ courts in the remaining Member States will continue to heed these rules in cases related to the UK even after its withdrawal from

\footnotetext{
40 Geert van Calster, European Private International Law (2d ed., Hart Publishing 2016) 3.

${ }^{41}$ See for example the Draft Common Frame of Reference (DCFR), a sort of model civil code for the EU. Its drafters have gone out of their way in their efforts to combine the common and the civil law tradition. See e.g. the situation-based rules on torts or 'non-contractual liability arising out of damage caused by another' (Art VI.-2:201 et seq. DCFR) or those on trusts (Book X DCFR).

${ }^{42}$ Regulation (EC) 864/2007 of 11 July 2007 on the law applicable to non-contractual obligations (Rome II), [2007] OJ L 199/40.

${ }^{43}$ Cf Art 2 Rome II Regulation.

${ }^{44}$ Art 3 Rome II Regulation.
} 
the EU. The treatment of the UK in this respect does not differ from relations of the EU with other third countries.

The Rome II Regulation will however no longer be binding on UK courts. There is also no forerunner that could take its place. A draft convention that would have contained conflict rules for non-contractual obligations has never been adopted. ${ }^{45}$ The UK is therefore free to fall back to its previous private international law, which was guided in principle by the application of lex loci delicti. ${ }^{46}$ In case of conduct and damage occurring in different countries, it gave prominence to the place of damage. ${ }^{47}$ This is similar to the Rome II Regulation. ${ }^{48}$ However, the UK's autonomous private international law misses clear-cut rules on applicable law issues such as product liability, competition law, or intellectual property law, not to speak of unjust enrichment and pre-contractual liability, which are all covered by EU conflicts law. ${ }^{49}$

One way for the UK legislator to fill this void is to copy and paste the Rome II Regulation into its domestic law. Whether Parliament will take this step is an open question. Another possibility is a treaty between the EU and the UK which replicates the provisions of the Rome II Regulation. But even if either of those routes were taken, it is doubtful whether European conflict of laws would function as smoothly as before Brexit. One aspect that drives the Rome Regulation's efficiency is their interpretation by the ECJ, which is binding all Member States' courts. It is unlikely that the ECJ's jurisdiction will readily be accepted by the UK, given that the Court of Justice was a main target of criticism by the Leave supporters. Interestingly, the dependency on "foreign judges" was also one of the arguments that fed the Swiss people's resistance against the EU in $1992 .{ }^{50}$ In order to keep Swiss law close to EU law, the Swiss legislator embraced the concept of "autonomous implementation", which considers ECJ judgments and other EU sources as relevant for construing Swiss legal rules that have been voluntarily taken over from European law. ${ }^{51}$ Another example is provided

\footnotetext{
45 Text reprinted in 38 (1974) Rabels Zeitschrift für ausländisches und internationales Privatrecht 211. On the draft, see O Lando, The EC Draft Convention on the Law Applicable to Contractual and NonContractual Obligations', ibid p. 6.

46 See Private International Law (Miscellaneous Provisions) Act 1995, sec 11(1).

47 Private International Law (Miscellaneous Provisions) Act 1995, sec 11(2).

${ }^{48}$ See Art 4(1) Rome II Regulation.

49 See Art 5-8, 10, 12 Rome II Regulation.

50 Cf. Willy Futterknecht (a prominent anti-EU agitator), 'EU Beitritt ? die 46 Souveränitätsverluste: Antwort auf die bundesrätliche Provkation' (Stans, Radika, 1994), p. 142.

51 Cf. Anton K. Schnyder, "Europäisches Gesellschaftsrecht und dessen „Nachvollzug" durch die Schweiz', in J Basedow, KJ Hopt and H Kötz, Festschrift für Ulrich Drobnig zum siebzigsten Geburtstag (Mohr Siebeck, Tübingen 1998), pp. 155 et seq.
} 
by the relationship of the ECJ and the EFTA court. While both are tied together by the mutual goal to develop and clarify the same European legislation, British courts' aligning interpretation of its own law would be a single-sided effort given that the ECJ is not bound, nor need to look at, the British courts at all.

Eventually, the model of Liechtenstein law could lead the way toward the right balance between autonomy and convergence. The Principality has a long tradition of importing legal transplants from Austria, Switzerland, Germany and - with regard to Liechtenstein trust law, one of its unique features as a civil law jurisdiction - the UK. Its courts consider judicial decisions from the transplant's country of origin to have an indicative albeit not binding effect for the interpretation of the same provision in Liechtenstein law. ${ }^{52}$ This way, the small Principality not only taps the rich case law provided by other states and fills a void left by the small number of cases handled by its courts. It also guarantees legal certainty and harmony with the EU's legal system. The UK could achieve the same objective through deeming the ECJ case law as precedents for purposes of the construction of its private international law. This would (1) enhance legal certainty, (2) keep the close relationship between (future autonomous) British and European conflicts of law intact, and (3) and achieve the benefits of a harmonious determination of the applicable law, such as the exclusion of incentives for forum shopping. Whether these benefits are sufficiently important for the UK to accept some influence of the ECJ on the interpretation of its law is another matter.

\section{Brexit's Impact on Company (Including Insolvency) Law}

\section{A. Consequences for Companies Incorporated under English Law}

Brexit may also spell trouble for corporations organized under English law and registered at the Companies House in Cardiff. ${ }^{53}$ The reason is that many continental laws treat EU and third-country corporations differently. Under the EU's fundamental

\footnotetext{
52 Cf. Supreme Court of the Principality of Liechtenstein (Oberster Gerichtshof des Fürstentums Liechtenstein - FLOGH), decision of 4 April 2002, 1 Cg 2000.64, LES 2005, 100 (107 f).; decision of 3 October 2002, 1 CG.1999.370; decision of 7 November 2002, 1 EG.2001/22; E Berger, Rezeption im liechtensteinischen Privatrecht unter besonderer Berücksichtigung des ABGB, 2nd. ed. (LIT, Vienna 2011), p. 235 et seq.

53 The consequences for companies organized under Scots or Northern Irish law are similar. These corporate forms are henceforth neglected as they have not much practical importance on the continent.
} 
freedom of establishment, companies organized according to the law of another Member State must be recognized and treated as companies organized under domestic law, independently of where their administration or activities are located. ${ }^{54}$ This result can best be achieved by applying the so-called 'incorporation theory', which holds that a company is governed by the law of the State in which it is registered or organized (which normally amounts to the same)..$^{55}$ With regard to companies organized under a third-country law, however, many Member States still follow the socalled 'real seat theory', according to which the law of the State where the company's head office is applies. ${ }^{56}$

The difference does not matter as long as a company is registered in the country of its head office and organized according to this country's corporate law. Companies incorporated and headquartered in England will thus continue to be recognized in EU Member States as English law companies even after Brexit. The situation will however be much more complex for those companies organized under English law that have their head offices on the continent. ${ }^{57}$ After the UK's departure

\footnotetext{
54 See Art 49 TFEU and the decisions applying it to foreign companies: ECJ, Case C-212/97 Centros Ltd v Erhvervs- og Selskabsstyrelsen [1999] ECR I-1459; Case C-208/00 Überseering BV v Nordic Construction Company Baumanagement GmbH [2002] ECR I-9919; Case C-167/01 Kamer van Koophandel en Fabrieken voor Amsterdam v Inspire Art Ltd [2003] ECR I-10155. From the literature, see WH Roth, 'From Centros to Ueberseering: Free Movement of Companies, Private International Law, and Community Law' (2003) 52 International and Comparative Law Quarterly 177; J Armour and WG Ringe, 'European Company Law 1999-2010: Renaissance and Crisis', Common Market L. Rev. 125 (2011); W Schön, 'The Mobility of Companies in Europe and the Organizational Freedom of Company Founders' [2006] European Company and Financial Law Review 122, 138; P Paschalidis, Freedom of Establishment and Private International Law for Corporations (OUP 2012).

55 On the incorporation theory, see e.g. Stephan Rammeloo, Corporations in Private International Law: A European Perspective (Oxford University Press 2001) 16.

${ }^{56}$ On the real seat theory, see e.g. S Rammeloo, Corporations in Private International Law: A European Perspective (Oxford University Press 2001) 11 et seq.; PL Davies and others, Gower and Davies' Principles of Modern Company Law (9 ed, Sweet \& Maxwell 2012), para 6-18 et seq. The real seat theory is followed for example by Austrian law: sec 10 Austrian Act on Private International Law (IPRG) and B Verschraegen, in P Rummel (ed), Kommentar zum Allgemeinen Bürgerlichen Gesetzbuch, vol 2/2 3 ed. (Manz 2002), § 10 IPRG paras 3 et seq. On French law: Art 1837(1) Code Civile and P Mayer $\&$ V Heuzé, Droit international privé, $7^{\text {th }}$ ed. (Montchrestien Paris 2001), p. 668, margin no. 1038; on Belgian Law: Art 110 Code of Private International Law (Code de droit international privé) and M Pertegas, 'The Belgian Code on Private International Law: A tour d'horizon', (2006) IPRax 53, 59; on German law: see German Federal Court (Bundesgerichtshof), judgment of 27 October 2008, II ZR 158/06, BGHZ 178, 192, 196-199. For a comparative overview, see RR Drury, 'Migrating Companies' (1999) 24 European Law Review 354, 356 et seq; J Lowry, 'Eliminating Obstacles to Freedom of Establishment: The Competitive Edge of UK Company Law', (2004) Cambridge Law Journal 331, 332; B Großfeld, 'Internationales Gesellschaftsrecht', in Staudinger, Kommentar zum Bürgerlichen Gesetzbuch, Einführungsgesetz zum Bürgerlichen Gesetzbuche/IPR, (Neubearbeitung, Sellier de Gruyter, Munich 1998), paras 153-154; P Kindler 'Internationales Gesellschaftsrecht', in Münchener Kommentar zum Bürgerlichen Gesetzbuch, 6th ed (CH Beck, Munich 2015), margin no 511.

57 The number can be considerable. Between 2004 and 2011, about 48,000 companies in Germany have been incorporated under English law, see WG Ringe, 'Corporate Mobility in the EU - A Flash in the Pan?', 2 (2013) European Company and Financial Law Review (ECFLR) 230, 248 (table). The
} 
from the Union, they will no longer benefit from the freedom of establishment under the TFEU. If the real seat theory is applied to them, they will be governed by the law of the State of their head office, e.g. by Austrian, Belgian, French or German law.

The consequences could be disastrous. According to the most radical version of the real seat doctrine, a company that is not organized under the governing law will be considered non-existent. ${ }^{58}$ As a result, assets and liabilities of English law companies on the continent will have no owners and become bona vacantia. ${ }^{59} \mathrm{~A}$ softer variant of the real seat theory suggests that the company continues to exist in the corporate form provided by the domestic law of the State where it has its seat. ${ }^{60}$ To illustrate, an English private limited company (plc) headquartered in Munich could become a Gesellschaft bürgerlichen Rechts $(\mathrm{GbR})$ as provided for under the German civil code. ${ }^{61}$ While the company would not lose its legal personality, the changes to its legal regime would be far from benign. The company's shareholders could no longer invoke the limitation of their liability which was a given as long as they were governed by English law. ${ }^{62}$ Acts taken by the management could be invalidated as the rules on the company's representation under English and German law are different. ${ }^{63}$

attractiveness of the English corporate form for German founders results mainly from the very low minimum capital requirements, the rapid incorporation procedure and the absence of co-determination, see Ringe, id. 238. The inverse situation, i.e. the incorporation of a company under German law with headquarters in the UK, is not known to the authors, although German law expressly allows it, see sec 4a German Act on private limited companies (GmbHG).

58 This version has been prevalent in Germany for a long time, see German Federal Court, BGHZ 53, 181.

59 Whether these assets fall to the English Crown is another problem, which is not yet resolved. Art 1012 Companies Act 2006 applies directly only to dissolved companies, not to those that are inexistent. It can moreover be argued that the provision only covers assets in the UK, see HP Mansel, in: H Krüger \& HP Mansel (eds.), 'Internationalprivatrechtliche Anpassung bei Liquidationsgesellschaften im deutsch-englischen Rechtsverkehr', in: Liber amicorum Kegel (CH Beck, Munich 2002), p. 111, 116; S Leible \& M Lehmann, 'Auswirkungen der Löschung einer Private Limited Company auf ihr in Deutschland belegenes Vermögen', (2007) GmbH-Rundschau, p. 1095 (on Art 654 Companies Act 1985); G Scanlan, M Lewis and Law Society (Great Britain) (eds), Companies Act 2006: A Guide to the New Law (Law Society 2007) 190.

60 This version has been adopted more recently by German courts, see BGHZ 151, 204.

${ }^{61}$ See sec 705 et seq. German Civil Code (BGB). The German corporate form corresponding to a plc would be a Gesellschaft mit beschränkter Haftung $(\mathrm{GmbH})$. However, incorporation as a $\mathrm{GmbH}$ is conditioned on certain steps, inter alia a registration, which the plc's founders have not undertaken.

62 On the consequences, see MP Weller, C Thomale and N Benz, 'Englische Gesellschaften und Unternehmensinsolvenzen in der Post-Brexit-EU', [2016] Neue Juristische Wochenschrift 2378, 2381; R Freitag and S Korch, 'Gedanken zum Brexit - Mögliche Auswirkungen im Internationalen Gesellschaftsrecht', 37 (2016) Zeitschrift für Wirtschaftsrecht (ZIP) 1361, 1363; W Bayer and J Schmidt, 'BB-Gesetzgebungs- und Rechtsprechungsreport Europäisches Unternehmensrecht 2015/16', 71 (2016) Betriebs-Berater (BB) 1923, 1933.

${ }^{63}$ See M Lehmann, 'Gründung der Gesellschaft', in S Leible \& J Reichert (eds.), Münchener Handbuch des Gesellschaftsrechts, vol 6, 3d ed (CH Beck, Munich 2007), p. 73 et seq. 
To avoid these unwelcome results, companies incorporated in England could try to adopt a more appropriate corporate form available under the law of the state of their real seat. While the restructuring laws on the receiving end are most likely open to such transformation, ${ }^{64}$ the reorganization costs may provide barriers for corporations that have often been formed with a capital of as little as one pound. Another possibility would be to create a company under the law of the real seat state and transfer the assets of the private limited or other English law company or partnership to it. Yet this is likely to face, as one of several struggles, the perspective of a hefty tax bill.

Legal action is therefore necessary. Note that the problem is essentially an EU one, with the UK probably having little interest in the fate of 'foreign' English law companies headquartered on the continent because they do not contribute to its economy. The initiative must therefore be taken by the country of the real seat, which is in addition the only one to have power of enforcement over companies with headoffices on their soil. There are different directions in which Member State's action could head.

First, the Member State might take the radical step to abandon the real seat theory altogether in favour of the incorporation theory. ${ }^{65}$ This would however have tremendous repercussions because it would not only allow the creation of new companies under English law in the real seat state, but also open its legal system to corporate forms from all other third countries, including very distant and unknown ones such as the Fiji Islands or Vanuatu. We doubt that many Member States will take this courageous path.

Second, a Member State could force English law companies headquartered in its territory to reorganize under its law within a certain timeframe. For instance, German commentators have suggested to require firms registered in the UK to reincorporate into a domestic corporate form within a grace period of two years after

\footnotetext{
${ }^{64}$ Neither ECJ case law nor the EU Directive 2005/56/EC applies to English companies after the Brexit. However, under the real seat doctrine the former Limited companies is treated as a partnership, and German transformation rules enable the transformation of a partnership into a $\mathrm{GmbH}$.

${ }^{65}$ See MP Weller, C Thomale and N Benz, 'Englische Gesellschaften und Unternehmensinsolvenzen in der Post-Brexit-EU', [2016] Neue Juristische Wochenschrift 2378, 2381.
} 
Brexit. ${ }^{66}$ Such a solution would not solve the cost problem and also engender considerable uncertainty if the grace period is not respected.

Third, the theory of 'vested rights' could be extended to the conflict of legal regimes in time. ${ }^{67}$ Vested rights theory is intimately related to conflict of laws and protects reasonable individual expectations as to the applicability of a certain law. ${ }^{68}$ The adoption of this doctrine to solve intertemporal conflicts does not necessarily require legislative intervention. Courts could emphasize that the founders of an English law company used the law of what was then a EU then Member State, and that they trusted in the continued application of English law. They could deem this trust to be legitimate and worthy of protection, as private persons cannot foresee such a groundbreaking change in the political landscape and should not suffer the risks resulting from it. We note that national company laws provide for doctrines with an outcome similar to vested rights which could also be utilized. ${ }^{69}$ In contrast to the first and second path of action, the vested rights doctrine would allow companies in the EU to continue to operate under English law. Some Member States might find this unacceptable. They could be especially worried that English law is applied dynamically, i.e. including amendments post-Brexit, thus giving the British lawmaker a continued influence on the corporate governance of EU companies. A solution to this problem could be to freeze the applicable English law at a certain moment in time, e.g. at the date of entry into force of the withdrawal agreement between the UK and the EU. But this would create a new set of problems: it would decouple the companies from sensible evolutions of English law, create a parallel petrified regime and probably spur considerable confusion as well as legal uncertainty.

Fourth, national legislators could foresee an automatic reincorpoation of English law companies under a legal form available in, or at least acceptable by, the country of their real seat. While this option requires legislative action (including

${ }^{66} \mathrm{R}$ Freitag and S Korch, 'Gedanken zum Brexit - Mögliche Auswirkungen im Internationalen Gesellschaftsrecht', 37 (2016) Zeitschrift für Wirtschaftsrecht (ZIP) 1361, 1364, suggest a period of two years after Brexit.

67 See the proposal by MP Weller, C Thomale and N Benz, 'Englische Gesellschaften und Unternehmensinsolvenzen in der Post-Brexit-EU', [2016] Neue Juristische Wochenschrift 2378, 23812382.

$68 \mathrm{~J}-\mathrm{J}$ Kuipers, EU Law and Private International Law: The Interrelationship in Contractual Obligations (Martinus Nijhoff Publishers, Leiden 2011) 303; R Michaels, 'EU Law as Private International Law? Reconceptualising the Country-of-Origin Principle as Vested-Rights Theory' (2006) 2 Journal of Private International Law 195, 219.

69 For instance, the German doctrine of 'the defective corporation' (fehlerhafte Gesellschaft) disregards certain procedural mistakes in a retrospective manner (while requiring active rectification for the future). 
specifying the date of reincorporation which may be hard to determine with the EU-UK negotiations pending), it seems preferable since automatic reorganization would reduce costs and enhance certainty. Moreover, it would also benefit the legal industry in the Member State in question by extending the scope of national corporate law.

\section{B. Consequences for British SEs}

There are a few companies with head offices in the UK that are incorporated as a Societas Europaea (SE). ${ }^{70}$ This corporate form will no longer be available in the post Brexit era because the SE Regulation not only requires that the company is set up in the territory of the Union, ${ }^{71}$ but also that its registered office and its head office are both located there. ${ }^{72}$ In order to maintain their legal form, British SEs must thus transfer their seat to one of the remaining Member States. This can be done by creating a new legal person without the need of any winding-up. ${ }^{73}$ Alternatively, British SEs may choose to rescind their status by reincorporating as companies under English, Scottish or Northern Irish law. The British lawmaker ought to take steps to facilitate a change to one of the latter laws if it wants to keep them on its territory.

\section{Consequences for Insolvency Proceedings}

In the years preceding the Brexit referendum, UK courts, lawyers and insolvency administrators have developed a profitable business model by restructuring companies from other EU Member States. Especially popular was the 'scheme of arrangement', which is not a proper insolvency proceeding, but a voluntary agreement between the company's creditors. ${ }^{74}$ In case of acceptance by a majority of $75 \%$ of the creditors, it binds all of them regardless of whether they have approved it. ${ }^{75}$ The scheme of arrangement offered an attractive way to impose a haircut on recalcitrant creditors the company.

\footnotetext{
${ }^{70}$ For example, Great Lakes UK has changed its legal form from a Public Limited Company under English law to that of an SE, see https://www.munichre.com/en/media-relations/publications/companynews/2015/2015-07-29-company-news/index.html (accessed 20 August 2016).

${ }^{71}$ Art 1(1) SE Regulation (Council Regulation (EC) No 2157/2001 of 8 October 2001 on the Statute for a European company (SE), [2001] OJ L 294/1). The Regulation still uses the term 'Community law'.

72 Art 7 SE Regulation.

73 See Art 8 SE Regulation.

${ }^{74}$ See Part 26 Companies Act 2006.

75 Sec 899 Companies Act 2006.
} 
The restructuring of companies from other Member States in the UK was made easier by Britain's wide interpretation of rules of jurisdiction. Thus, it was considered that companies could have their centre of main interest (COMI) in England even if they had moved there very recently. ${ }^{76}$ This opened the way to conduct insolvency proceedings of continental companies under UK law. The scheme of arrangement is applied not only to companies organized under English law, but also to foreign companies provided they have a 'sufficiently close connection' to the UK, that there is a reasonable possibility of benefit accruing to creditors from the scheme, and that one or more persons interested in the distribution of assets are persons over whom the English court could exercise jurisdiction (so-called 'core requirements'). ${ }^{77}$ English courts consider these three core requirements as discretionary and not as limiting their jurisdiction, which provides them with additional leeway. ${ }^{78}$ As a surplus, they construct the three criteria in a very wide manner. In particular, they consider there to be a 'sufficiently close connection' to the UK if the agreement which is the subject of the scheme is submitted to English law and to the jurisdiction of UK courts. ${ }^{79}$ On top of this, they consider the selection of English forum and ius to be sufficient even where it is made ex post by a supermajority of the creditors. ${ }^{80}$ They thereby allow free choice of the scheme for all practical purposes.

The expansive view of British insolvency jurisdiction and scheme applicability has led to the emergence of a great deal of 'insolvency and restructuring tourism' to the UK. Until now, other Member States were required to recognize British insolvency measures and decisions under the European Insolvency Regulation. ${ }^{81}$ With regard to schemes of arrangement, there was a certain tendency to consider them as falling under the Brussels I Regulation, with the effect that they would have to be recognized as well. ${ }^{82}$

\footnotetext{
76 See e.g. Hellas Telecommunications (Luxembourg) II SCA [2009] EWHC 3199 (Ch); European Directories v (DH6) BV (Re European Directories) [2010] EWHC 3472 (Ch). This solution is however made more difficult by the recast of the European Insolvency Regulation (Regulation (EU) 2015/848 of 20 May 2015 on insolvency proceedings, [2015] OJ L 141/19), see its Art 3(1) subpara 2.

77 The practice was based on sec 895(2)(b) Companies Act 2006, which opens the scheme to companies that are 'liable to be wound up under the [British] Insolvency Act 1986'. The three cited judicial 'core requirements' have been developed in Real Estate Development Co [1991] BCLC 210, per Knox J at 217, approved by the Court of Appeal in Re Latreefers Inc [2001] BCC 174.

${ }^{78}$ Re Drax Holdings Ltd [2004] 1 WLR 1049, per Lawrence Collins, at para 23-26.

79 See Re Rodenstock GmbH, [2011] EWHC 1104 (Ch), para 68.

${ }^{80}$ Re Apcoa Parking Holdings GmbH, [2014] EWHC 3846 (Ch), para 230-231.

${ }^{81}$ Art 19(1) European Insolvency Regulation (Recast).

82 See e.g. in Germany: Federal Court (BGH), (2012) Neue Juristische Wochenschrift 2113, margin no. 26; M Brinkmann, InsO § 355, in K Schmidt, Insolvenzordnung, 19 ed (CH Beck 2016), margin no 10;
} 
Brexit will fundamentally change this situation. The European Insolvency Regulation will cease to apply to British insolvency measures and judgments originating in the UK. They will instead be governed by the differing rules of the Member States for third-country insolvencies. ${ }^{83}$ The latter often contain special hurdles for recognition. This may include, e.g., the control of the foreign insolvency court's jurisdiction and the compatibility of its decision with domestic public policy. ${ }^{84}$ Though the Brussels Convention will continue to apply, ${ }^{85}$ continental courts might show less willingness to apply its rules to recognize and enforce British schemes of arrangements. Moreover, since the freedom of establishment will be abandoned in relation to the UK, it will no longer be possible to move companies to the UK with the goal of winding them up there. 'Insolvency and restructuring tourism' to Britain will therefore come to an end.

\section{Financial Law}

\section{A. Passporting Concept}

In contrast to many other fields of European business law, financial services law is characterized by licensing requirements. Without a license granted by a financial authories of a Member State, financial services firms are subject to a prohibition to provide services in the EU. By virtue of a so-called European passport, the effect of a license granted by the financial firm's home Member State is extended to all EU and EEA Member States. Due to a fragmented licensing scheme, many different types of passports path the way into the European Single Market for financial services.

\footnotetext{
Peter Mankowski, 'Anerkennung englischer Solvent Schemes of Arrangement in Deutschland', WM 2011, 1201, 1203-1206; O Sieg and S Blum, 'Solvent Schemes - Enforceability in Germany', in: Globale Rückversicherungs-AG (ed), Managing Run-off in Europe Solvent Schemes and Other Aspects (Global Reinsurance Group, Cologne 2007) 47 (49 et seq.).

${ }^{83} \mathrm{~B}$ Hess, 'Back to the Past: BREXIT und das europäische Internationale Privat- und Verfahrensrecht, 36 (2016) IPRax 409, 416; J Ungerer, 'Brexit von Brüssel und den anderen EU-Verordnungen zum Internationalen Zivilverfahrens- und Privatrecht' (2016) Zeitschrift für das Privatrecht der Europäischen Union [forthcoming special edition]; MP Weller, C Thomale and N Benz, 'Englische Gesellschaften und Unternehmensinsolvenzen in der Post-Brexit-EU', [2016] Neue Juristische Wochenschrift 2378, 2382. ${ }^{84}$ See e.g. sec 343 German Insolvency Act (Insolvenzordnung), which excludes recognition of foreign insolvency proceedings where the third-country court was not competent from a German viewpoint or where recognition would lead to a result that is incompatible with German public policy. The provision applies both to the recognition of insolvency proceedings and decisions, see; M Brinkmann, InsO $\S$ 353, in K Schmidt, Insolvenzordnung, 19 ed (CH Beck 2016), margin no 1.

${ }^{85}$ See infra Part VI, para 3.
} 
Passported activities include, for instance, the distribution of financial services, asset and fund management, as well as credit and insurance business. By virtue of a passport, financial firms may act on a cross-border basis or set up a branch in the host Member State as if it was licensed there.

As of now, European passports are reserved to firms located in Member States. Unless the UK seeks the status as a member of the European Economic Area (see SUPRA, I.A.), they will not be available for UK firms. Even the status of an EEA country would not necessarily result in full market access. It has to be borne in mind that the EEA countries were prevented from entering crucial parts of the EU financial market after the adoption of three omnibus directives creating the European Supervisory Authorities ESMA, EBA and EIOPA. For instance, the implementation of the Directive on Alternative Investment Fund Managers (AIFMD) into the EEA acquis took more than three years. ${ }^{86}$ After all political questions had been solved, the technical implementation started, which has as of now required another two years. At the time this article is written, i.e. more than five years after the AIFMD's entry into force, the EEA countries still lack market access for AIFs. Under the current terms, market access may be denied in case of any change of EU law until the EEA agreement is adapted. This means that the EU sets the terms and EEA-only Member States must follow suit. The UK would be ill-advised to bet on the administrative efficiency and willingness of European institutions in the absence of institutional reforms of the EEA agreement. Such an institutional reform could take one of two ways. First, market access could be allowed to all EEA-only Member States that accept the EU rules before the EEA agreement is amended. Second, the order could be reversed: market access is to be granted under the old terms unless the new terms have been transposed into the EEA agreement or a certain grace period - e.g. of up to five years - is expired.

\section{B. Country-by-country Access}

Most financial relationships with third countries, in particular all services targeted at retail clients and retail investors, are governed by national law. For instance, the

\footnotetext{
86 In October 2014, the EEA states and the European Commission had finally found a political agreement. For a description of the procedures and its impact on EEA countries see $P$ Bont \& $D$ Lötscher, 'Challenges from the Supervisor's Perspective', in D Zetzsche (ed.), AIFMD, $2^{\text {nd }}$ ed. (Kluwer Law International, The Hague 2015), p. 85, 90 et seq.
} 
Directive on Undertakings for the Collective Investment in Transferable Securities (UCITS Directive) provides that Member States regulate their relationship vis-à-vis third country firms independently. ${ }^{87}$ For that purpose, the Directive imposes a nondiscrimination rule (i.e. firms from third countries must not be treated more leniently than those from Member States) as well as the right of third country entities to enter the European market by establishing subsidiaries that will be subject to all provisions of European law. ${ }^{88}$ Similarly, the Directive on Managers of Alternative Investment Funds (AIFMD) allows for a country-by-country authorization scheme for third country managers of alternative investment funds. ${ }^{29}$ These National Private Placement Regimes (NPPR) continue to be available in some Member States after the entry into force of the AIFMD. ${ }^{90}$ However, the EU Commission must decide by 22 January 2019 whether to phase them out. ${ }^{91}$ As long as these regimes are available, British firms may only rely on some Member States' NPPRs. Furthermore, many Member States have added national provisions to the minimum requirements set by the AIFMD. ${ }^{92}$ Reliance on NPPRs will thus open some markets for British firms, but comes at heavy costs because they will need to meet many different national requirements.

In order to achieve further legal certainty, some third countries have entered into bilateral agreements that grant their firms access to the Single Market, but require the same for firms from EU Member States. For instance, Swiss fund management companies received the right to distribute UCITS-equivalent investment funds to German retail investors, while German UCITS management companies were granted the right to enter the Swiss market. ${ }^{93} \mathrm{~A}$ bilateral strategy could open certain key parts

\footnotetext{
87 See Article 9(1) UCITS Directive (Directive 2009/65/EC of the European Parliament and of the Council of 13 July 2009 on the coordination of laws, regulations and administrative provisions relating to undertakings for collective investment in transferable securities (UCITS), [2009] OJ L 302/32).

${ }^{88}$ For details see D Zetzsche, 'Drittstaaten im Europäischen Bank- und Finanzmarktrecht', in G Bachmann \& B Breig (eds.), Finanzmarktregulierung zwischen Innovation und Kontinuität in Deutschland, Europa und Russland (Mohr Siebeck, Tübingen 2014), p. 49, 69 et seq.

89 Art 36, 42 AIFMD (Directive 2011/61/EU of the European Parliament and of the Council of 8 June 2011 on Alternative Investment Fund Managers and amending Directives 2003/41/EC and 2009/65/EC and Regulations (EC) No 1060/2009 and (EU) No 1095/2010, [2011] OJ L 174/1).

90 See D Zetzsche, Introduction (p. 20), and D Zetzsche \& T Marte, 'The AIFMD's Cross-Border Dimension and Third Country Rules - A Systematic Perspective', in D Zetzsche (ed.), AIFMD, $2^{\text {nd }}$ ed., (Kluwer Law International, The Hague 2015), pp. 431, 450 et seq.

${ }^{91}$ Article 68(6) AIFMD.

${ }^{92}$ For an overview see the AIFMD's implementation country-by-country in Zetzsche (ed.), AIFMD, $2^{\text {nd }}$ ed., 2015, chapters 28-37, pp. 729 et seq.

${ }^{93}$ See Swiss Ministry of Finance (Eidgenössisches Finanzdepartment) and German Ministry of Finance (Bundesministrerium der Finanzen), 'Memorandum zu verfahrensrechtlichen Aspekten grenzüberschreitender Tätigkeiten im Finanzbereich' ('memorandum on procedural aspects of crossborder activities with regard to financial services'), July and August 2013, sub 3 . The basic
} 
of the EU market to British financial services firms, in particular access to retail investors. This will however require painstaking negotiations and a clear determination which national interests should prevail, given that only few key priorities can be pushed through. Similar to the situation with Switzerland, we assume the result of bilateral agreements to look rather patchy, and thus costly to manage for financial firms. We do not expect large scale access to retail clients and retail investors to be granted by the EU to British firms.

\section{Third Country Passports and Equivalence}

When financial services are distributed to professional investors, the more modern European financial law directives and regulations adopt a supra-territorial approach. ${ }^{94}$ For instance, the Markets in Financial Instruments Regulation (MiFIR) and the AIFMD state allow third country firms to obtain a passport which permits them to provide financial services to professional investors and manage alternative investment funds that can be distributed to professional investors in all Member States. ${ }^{95}$ While the EU has some experience with giving access to third country securities offerings under the Prospectus Directive ${ }^{96}$ granting passports to intermediaries and thus all of their products is a relatively novel evolution. The European legislator has foreseen safeguards to protect European investors and the financial system alike: For instance, the AIFMD makes the passport for third country firms subject to a lengthy approval procedure that incluces ESMA, the European Commission, the Council and the Parliament as well as the competent national authorities. ${ }^{97}$ The outcome of this process is uncertain. Market access may or may not be available for third country fund managers, or made subject to certain conditions. In addition, the introduction of the AIFMD's third country platform has been suffering from considerable delay. As of now it is uncertain whether it will be available before the AIFMD's first review which is going to start in 2017.98

\footnotetext{
agreement has been implemented by virtue of an implementing ordinance (“Ausführungsverordnung"). For details see FINMA-Mitteilung 54 (2014) of 6 Januar 2014.

${ }^{94}$ See D Zetzsche \& T Marte (n. 90), Ch. 16.

${ }^{95}$ Art 28(1)(d), 47 MiFIR, Art 37 and 38 AIFMD.

${ }^{96}$ Cf. Article 4(1) of the Propectus Directive 2003/71/EC, as amended by the Directive 2010/73/EU.

${ }^{97}$ See Art 67 AIFMD.

${ }^{98}$ See European Commission, Letter to ESMA, Ares(2015)5921711 - 17/12/2015.
} 
The Third Country Passports grant the right to provide services to professional investors to non-Member States firms if the regulation as well as the supervision of the third country meets the equivalence test. ${ }^{99}$ The core elements of this test are the duality of equivalent substantive law and equivalent enforcement by the third country authorities. ${ }^{100}$ In particular, the financial intermediary must be subject to (1) legally binding rules which are equivalent to those set out in European law, (2) authorisation or registration requirements and (3) effective supervision and enforcement on an ongoing basis. In addition, cooperation agreements must ensure that Member States' authorities can rely on the information gathered by the supervisory authority in the third country. ${ }^{101}$ The agreements are negotiated centrally on behalf of all Member States by the European Commission and the ESAs. This means that British supervisory authorities will have to enter into cooperation agreements with European institutions before the UK regime can be considered equivalent with that of the EU.

In practice, the equivalence requirement has not proved to be a major barrier for important financial centres. For instance, ESMA has recently deemed the US regulation on private investment funds as being equivalent to the AIFMD despite the fact that US depositaries neither are obliged to control the fund manager nor are strictly liable for the safe keeping of the fund's assets. It also did not bother ESMA that US law neither restricts the AIFM personal's remuneration nor imposes a leverage control similar to EU law. If this lenient strategy is continued, we expect British law and practice to be deemed equivalent, as long as it does not change radically after Brexit.

\footnotetext{
${ }^{99}$ See Art. 46 MiFIR and Recital 42 MiFIR (stating that a third country firm may not provide investment services to eligible counterparties and to professional clients unless they are registered as equivalent third country firms); Article 36-42 AIFMD (regulating third country AIF managers and third country alternative investment funds and distributed to professional investors based on the equivalence principle). On the equivalence concept, see D Zetzsche, 'Competitiveness of Financial Centers in Light of Financial and Tax Law Equivalence Requirements', in: R Buckley, D Arner \& E Avgouleas (eds.), Rethinking Global Financial Law and Its Regulation (Cambridge University Press, Cambridge 2016) 390; T Wei, The Equivalence Approach to Securities Regulation, 27 Northw. J Int'I L. \& Bus. 255, 257 (2007) (with regard to securities regulation); E Ferran \& LC Ho, Principles of Corporate Finance Law 417-419, 2d ed. (OUP, Oxford 2014) (deeming equivalence the practical substitute for convergence, aiming at substantial rather than full convergence of securities laws); R Weber \& R Sethe, 'Äquivalenz als Regelungskriterium im Finanzmarktrecht', 110 Schweizerische Juristen-Zeitung 569 (2014).

100 See, for instance, Art. 28 (4), 47 (1) MiFIR; Article 37 (2) and 8 and 38 AIFMD. For details, see D Zetzsche \& T Marte (supra, n. 90), at 431, 469 et seq.

101 See Recital 17 and Art. 5 (6) Rating Regulation; Art. 25 (4) c) and (10) of CSD Regulation; Art. 55 57, 115 CRD IV; Art. 68 Solvency II; Art. 76 EMIR; Art. 88 MiFID II; Art. 47 (2) MiFIR; Recital 39, Art. 38 Short Selling Regulation; Recital 69, Art. 26 Market Abuse Regulation; Recital 63, 69, 74, Art. 34 (2) b), 35 (2) a), 36 (1) b), 37 (7) d), 40 (2) a), 42 (1) b) AIFMD.
} 


\section{Some Surprising Additional Requirements}

If the UK were to become a third country and try to access the Single Market via the equivalence test, it would nevertheless have to accept some unexpected disadvantages. These have been created by EU financial law. For instance, Article 46(7) MiFIR states:

'Third-country firms providing services or performing activities in accordance with this Article shall, before providing any service or performing any activity in relation to a client established in the Union, offer to submit any disputes relating to those services or activities to the jurisdiction of a court or arbitral tribunal in a Member State.'

Some commentators infer from this clause an 'explicit prohibition' to agree on English courts with regard to any litigation falling under the scope of MiFIR. ${ }^{102}$ Yet the text does not go so far. It merely requires countries from third firms to offer a forum in the EU. Nevertheless, even this interpretation is likely to diminish the importance of London as a centre for securities litigation. For long, the ISDA Master Agreement, which governs most derivatives contracts, merely provided a choice between English courts and the US District Court in Manhattan. ${ }^{103}$ Only recently, an arbitration option has been added. Some of the arbitration institutions designated by ISDA have their seat in the EU, others can organize arbitrations there. One can argue whether this is sufficient to comply with the requirements of Article 46(7) MiFIR. But merely offering the choice between English and U.S. courts will no longer suffice.

The purpose of Article 46(7) MiFIR is to protect European investors from having to litigate outside of the EU. ${ }^{104}$ The main thrust of the provision is therefore related to jurisdiction. ${ }^{105}$ However, its intended impact may also go much further: the provision may also have been drafted with a view to secure the application of MiFID II and MiFIR as mandatory European law. Member States' courts are bound to apply to all the EU rules regardless of the law that has been chosen because of their nature as overriding mandatory provisions in the sense of Article 9 Rome I and Article 16 Rome II. MiFID II and MiFIR will thus prevail in European courts over any law chosen in an agreement

\footnotetext{
102 B Hess, 'Back to the Past: BREXIT und das europäische Internationale Privat- und Verfahrensrecht, 36 (2016) IPRax 409, 411.

103 Sec. 13 ISDA Agreement 2002.

104 Recital 41 MiFIR.

105 See R Sethe, 'Das Drittstaatenregime von MiFIR und MiFID II', Schweizer Zeitschrift für Wirtschaftrecht 2014, 615, 627.
} 
by the parties. As a result, English and New York law - so far, the only legal systems that can be chosen under the ISDA Master Agreement - will be superseded by MiFID II and MiFIR in court litigation. An arbitral tribunal sitting in the EU is likely to adopt the same interpretation. Although arbitral tribunals are technically not bound by legislation of the country where they reside, their award could be set aside by its forum's courts, e.g. on the basis of a violation of the forum's public policy. We hold that at least certain mandatory requirements of MiFID II and MiFIR are part of (European) public policy. ${ }^{106}$ Once an award that disregards these rules has been set aside by a European court, other countries may refuse its recognition and enforcement. ${ }^{107}$ Intermediaries must consider this far-reaching effect of EU law prior to offering the service to clients located in Member States.

\section{E. Incorporation vs. Branches}

In response to the foreseeable passporting issues, one option that some British financial firms may consider is to incorporate within the EU/EEA, while retaining significant activities in the UK. This approach seems feasible only to a certain extent. Since the "post-BCCl" Directive, ${ }^{108}$ all financial services firms providing services in the EU are required to incorporate where their head office is located. The purpose of this rule is ensure their efficient supervision. It sets a clear limit to any split between the real and the registered seat of a financial firms. While one may imagine a certain division of labour between the company's UK and the EU offices, this division must not impair the head office function of the EU location. One can infer that all strategic decisions must be taken at the head office. Going even further, some national supervisory authorities have taken the view that the exercise of passporting rights requires a certain degree of activity from within a Member State. For instance, while third country entities may provide preparatory and supporting functions with regard to the distribution of financial services, it has been demanded that the clients' main contact must reside in a Member State. Besides, European service providers are

\footnotetext{
${ }^{106}$ For instance, the licensing requirements, the capital requirements for investments firms under CRD (Capital Requirements Directive) IV as well as the operating requirements are part of the public policy. For details, see M Lehmann and D Zetzsche, 'Brexit und Finanzmarktrecht', AG 2016 (forthcoming). 107 Art V(1) lit e United Nations Convention on the Recognition and Enforcement of Foreign Arbitral Awards, signed in New York on 10 June 1958).

108 See Directive 95/26/EC of the European Parliament and the Council of 29 June 1995 .. with a view to reinforcing prudential supervision, Recital 7 (“... whereas a financial undertaking which is a legal person must be authorized in the Member State in which it has its registered office ...").
} 
prohibited from outsourcing key functions to third country firms or to third country branches of EU firms. While European rules and interpretation as of now are characterized by a certain degree of flexibility, their interpretation by European authorities are likely to become more rigid should British firms try to push the limits of the passporting system.

\section{F. Loss of Representation of British Interests}

A certain degree of ambiguity has always been a characteristic feature of European financial law. This ambiguity is due to the pressure to find a compromise position among many different governmentss and authorities. While a mere nuisance in the past, it threatens to become risk for future EU-UK relations.

To illustrate, the Solvency II governing insurance undertakings provides two concepts for determining the location of business - the location of risk or the location of client approach. ${ }^{109}$ While the concepts come to the same result in most cases, the outcome differs where a corporate client insures risks located in a (Member or third country) State different from his place of incorporation. Interestingly, almost all continental jurisdictions have adopted the location of risk approach, with the UK being the eminent example of the location of client approach. When both concepts collide, as of now, the authorities discuss which authority is in charge. If they continue to disagree, EIOPA is to moderate the discussion, and, if disagreement persist, address an individual, binding decision to the intermediary in question. ${ }^{110}$

We find a similar ambiguity with regard to the limits of what constitutes an alternative investment fund. The British Financial Conduct Authority (FCA) is willing to consider pre-existing groups other than family offices - for instance friends that frequently make investments together - to fall outside of the AIFMD's scope, while most continental authorities deem these groups to be within the scope, and thus subject to the AIFMD's licensing requirement. ${ }^{111}$ We find similar ambiguity in other

109 Cf. Recital 77 and definition of host Member State in Art 13 No. 9 Directive 2009/138/EC ... of 25 November 2009 on the taking-up and pursuit of the business of Insurance and Reinsurance (Solvency II)., O.J. L 335/1 as of 17 December 2009, as amended

110 Cf. Art 19 Regulation (EU) no. 1094/2010 ... of 24 November 2010 establishing a European Supervisory Authority (European Insurance and Occupational Pensions Authority), (...), O.J. L331/48 as of 15 December 2010.

111 Cf. D Zetzsche \& C Preiner, Scope of the AIFMD, in D Zetzsche, AIFMD, 2nd ed. (Kluwer Law International, The Hague 2015), p. 39, 60 et seq. 
important parts of European financial law, despite the EU's commitment to develop a Single Rule Book.

In the past, this ambiguity provided room for regulatory arbitrage within European financial law. In particular, it allowed certain unlicensed third country vehicles to be established and to operate from the UK. In the future, the British authorities are likely to be prevented from protecting their national interests in the ESMA, EIOPA, EBA and ESRB working groups. With the British authorities being limited to a mere visitor status similar to that of the Swiss FINMA or Swiss Central Bank, we also expect a number of less ambiguous and more rigid decisions by the European Supervisory Authorities. This may prove harmful for British interests since correcting the position will require bilateral negotiations against the joint position of all national and EU supervisory authorities. Only EEA membership would avoid this degradation of British authorities.

\section{International Litigation}

The Brussels la Regulation contains a highly effective mechanism for cross-border litigation. It strengthens the Internal Market by providing rules on jurisdiction and lis pendens in civil and commercial matters, and guarantees the recognition and enforcement of judgments in this area. ${ }^{112}$ After Brexit, the Regulation will no longer apply to the relations between the UK and the EU. This may lead to renewed conflicts over jurisdiction, parallel proceedings and difficulties in the transnational enforcement of judgments.

The Regulation's functions could at least partly be guaranteed by the continued application of the Brussels Convention concluded in 1968. ${ }^{113}$ In 2001, it was replaced by the Brussels I Regulation with the aim to transform the Convention into a EU law

\footnotetext{
112 Regulation (EU) no. 1215/2012 of 12 December 2012 on jurisdiction and the recognition and enforcement of judgments in civil and commercial matters (recast) OJ L 351, 20.12.2012, p. 1. On the importance of the Brussels la Regulation for international civil litigation, see Andrew Dickinson, 'Background and Introduction to the Regulation', in A Dickinson \& Eva Lein (eds.), The Brussels I (Recast) Regulation (Oxford University Press, OUP 2015), para 1.03.

${ }^{113}$ Brussels Convention of 27 September 1968 on jurisdiction and the enforcement of judgments in civil and commercial matters, [1972] OJ L 299/32. The Convention has been amended several times at the occasion of new Member States to the then EEC or EC. The latest amendment occurred by the Convention of 29 November 1996 on the accession of the Republic of Austria, the Republic of Finland and the Kingdom of Sweden. A consolidated version of the Convention can be found in [1998] OJ C 27/1. It is this version which would be applicable after Brexit.
} 
instrument. The relation between the Brussels la Regulation and the Brussels Convention closely resembles that between the Rome I Regulation and the Rome Convention. ${ }^{114}$ Recital 9 Brussels la Regulation even makes it expressly clear that the 1968 Brussels Convention "continues to apply" to certain territories of Member States that do not fall under the Regulation's scope, and Art 68(1) uses the term "supersede" to describe the relation between the Convention and the Regulation for all other territories. The better arguments therefore speak in favour of a continued existence of the Brussels Convention and its reapplication after the UK's exit from the EU. ${ }^{115}$

Yet the applicability of the Brussels Convention far from removes all grounds for worries. Three important problems remain. The first is that the geographical scope of the Brussels Convention only partly covers that of the Brussels I Regulation. Due to the fact that 13 Member States - mainly Eastern and Southern European countries - acceded to the EU only after the Convention had been transformed into a Regulation, they had never been bound by the former. ${ }^{116}$ The courts of these states will therefore not be obliged to suspend proceedings in favour of British courts first seized or recognize and enforce judgments rendered in the UK. The second point is that the Convention's regime differs in more than one respect from that of the Regulation. For instance, it does not contain the single head of jurisdiction for contractual disputes regarding contracts for sale of goods and services. ${ }^{117}$ Recognition and enforcement of judgments under the Convention's regime is still predicated on a special declaration by the host state that the foreign judgment has legal force within its territory - the exequatur-, a requirement which has been abolished by the Brussels la Regulation. ${ }^{118}$ Another example of a deviation is a new provision in the Regulation seeking to exclude dilatory litigation tactics (the so-called "Italian torpedo") in case the parties have entered into a choice-of-forum agreement. ${ }^{119}$ Courts and parties in the

\footnotetext{
114 See supra Part II A.

115 A Dickinson, p. 205; J Ungerer, supra $n$ 22. For a different view, see B Hess, 'Back to the Past: BREXIT und das europäische Internationale Privat- und Verfahrensrecht, 36 (2016) IPRax 409, 413.

116 These countries are: Bulgaria, Croatia, Cyprus, the Czech Republic, Estonia, Hungary, Latvia, Lithuania, Malta, Poland, Romania, Slovenia and Slovakia.

117 See Art 7(1)(b) Brussels la Regulation.

118 See Recital 26 and Art 39 Brussels la Regulation.

119 Art 31(2) and (3) Brussels la Regulation. The "Italian torpedo" is a tactic whereby one party seizes the courts of a Member State with a notoriously slow judicial system despite the fact that they have no jurisdiction over the matter. It seeks to exploit the fact that under the Brussels Convention lis pendens rules this court had to first declare itself to be without competence before litigation could be continued in another Member State, see ECJ, Erich Gasser GmbH v MISAT Srl., Decision C-116/02, margin no 8. Such a declaration could potentially take years and thereby delay the proceedings considerably. Art 31(2) and (3) Brussels la Regulation have been drafted to exclude this tactic, see Francisco Garcimartin
} 
UK may come to sorely miss those improvements, as may creditors in the EU in relation to debtors domiciled in Britain. A further drawback relates to the case-law rendered by the ECJ under the Brussels I Regulation. It is doubtful whether it can be applied to the Brussels Convention. One may argue for such an extension where the provisions are identical or amended only in parts that were not relevant to the ECJ's ruling, but the question is far from clear and creates considerable uncertainty.

The British retreat from the EU will also complicate judicial cooperation with Switzerland, Norway and Iceland. These three states are bound to the EU by the Lugano Convention in its second version dating from 2007, which basically copies the provisions of the Brussels I Regulation and extends their scope to the EFTA States (with the exception of Liechtenstein). ${ }^{120}$ Because the Convention has been signed by the EU and not by its Member States, the UK will not be able to rely on it after Brexit. It was different for the original Lugano Convention signed in 1988, which has been signed and ratified by the Member States of the then EEC, including the UK, and the EFTA States Switzerland, Norway and Iceland (later also by Poland). ${ }^{121}$ Yet this original Convention has been completely replaced by the later one. The terms of 2007 Convention leave no room for a continued application of the 1988 Convention in any territory of a contracting State. ${ }^{122}$ Andrew Dickinson has voiced some doubts as to the EU's power to effectively terminate a Convention that has not been concluded by the Union itself. ${ }^{123}$ Yet Art 216(2) TFEU makes it clear that the EU has the authority to enter into international agreements with third States that are binding upon the Member States, which comprises the power to terminate existing obligations undertaken by the latter. The Lugano Convention 2007 will therefore not apply to the UK after its EU exit. Practically this means that it will be difficult to enforce British judgments in Switzerland, Norway and Iceland, and vice versa.

In sum, the UK's withdrawal from the EU will make cross-border litigation in Europe more difficult. Action in this area is therefore urgently needed. The Brussels I

in A Dickinson and Eva Lein, The Brussels I (Recast) Regulation (Oxford University Press 2015), para 11.41 .

${ }^{120}$ Convention on jurisdiction and the recognition and enforcement of judgments in civil and commercial matters, concluded at Lugano on 31 October 2007, [2007] OJ L339/3.

${ }_{121}$ Convention on jurisdiction and the enforcement of judgments in civil and commercial matters, concluded at Lugano on 16 September 1988, [1988] OJ L319/9.

122 See Art 69(6) Lugano Convention 2007.

${ }^{123}$ A Dickinson, 'Back to the Future: The UK's EU Exit and the Conflict of Laws', (2016) Journal of Private International Law 195, 207. 
Regulation and the Lugano Convention have been very successful instruments in the past, a fact that is widely recognized even in Britain. At the same time, judicial cooperation in civil matters is in both the EU's and the UK's interest independently of the shape of their future economic relationship. It is therefore likely that they will reach an agreement on this topic. As a model for implementation, one could look to the treaty concluded between the then European Community (EC) and Denmark in 2005, which extends the scope of the Brussels I Regulation to their relations. ${ }^{124}$ The UK could also become a party to the Lugano Convention 2007, which is not only open to EFTA, but also to other States, provided that all signatories agree. ${ }^{125}$ It is hard to imagine that the EU would deny such consent, given its interest in judicial cooperation with the UK.

\section{Conclusion}

The future coherence of EU - UK commercial relations depends on three aspects: a) the status of the UK, b) the level of autonomy which the UK government and its people wants to exercise once it can deviate from EU law, and c) the outcome of bilateral negotiations which will start once the British government has issued the notice foreseen in Article 50 TEU.

The three factors are correlated with each other, although not to the same extent:

1) While a pure third country status would seemingly provide full autonomy, it would come at the greatest costs for the British economy in terms of Single Market access. The UK could try to balance them by trade agreements with countries outside the EU, exercising the 'autonomy' large parts of its population are craving for. This will howver require lengthy negotiations, which can only start once Brexit is completed and the power to shape its own trading relations is reverted back to the UK. In the meantime, a pure GATT and GATS regime will apply. The Most-Favoured Nation Clause in these agreements will prevent the UK from discriminating between EU and non-EU firms. It will be effectively forced to extend any advantage it offers to third countries to European firms without receiving any consideration in return. It thus faces the unattractive choice of either having to impose high tariffs on all imported products

\footnotetext{
${ }^{124}$ Agreement between the European Community and the Kingdom of Denmark on jurisdiction and the recognition and enforcement of judgments in civil and commercial matters, [2005] OJ L 299/62.

125 See Art 70(1)(c) Lugano Convention 2007.
} 
or opening its markets to the whole world. The prospects for obtaining beneficial trade agreements with the rest of the world post-Brexit are also not as bright as it may seem. While some Commonwealth countries have voiced their willingness to open doors further for UK firms, they will eventually take into account that the EU is a much bigger market and therefore a more attractive trade partner than the UK. The perspective that the EU can be rationally expected to demand the same or even better treatment than the UK from its trading partners clouds the prospects for successful British negotiations with third coutries. ${ }^{126}$ Even worse, the pure third country status opens a Pandora's box full of potential issues of conflict with the EU on the UK's future trade partners. The EU bodies would be ill-advised to lend a hand to the UK's ambitions of prospering outside of the Single Market.

2) An EEA status would secure market access for British firms, but reduce the UK's autonomy, probably behind the level is currently experience as important EU member. Moreover, under the current design of the EEA the UK would be exposed to the risk of political influence on EU level which may result in a less-than-expected market access.

3) Bilateral agreements have serious disadvantages. They are costly to negotiate, and even more costly to maintain. Their outcome will remain uncertain and unstable for years. On the upside, bilateral agreements may result in a greater degree of British freedom to negotiate market access with other third countries than an EEA membership. However, any advantage granted to third countries will result in either granting the same benefit to EU firms, or impair the UK's equivalence status.

The dream of 'a Delaware at Europe's border' is therefore unmasked as an unrealistic option. The more prudent voices in the British government want to curb migration and maintain Single Market access. This could be achieved, e.g., by a reform of the EEA. One should however not expect the EUto sell its key asset - market access - at low costs given that such a move would inspire other Member States to follow. Furthermore, a reform of the EEA would take years and would be difficult to

\footnotetext{
126 This may explain the cold shoulder British PM Theresa May experience in Beijing and in the U.S.. Cf. The Guardian, Theresa May joins G20 summit to face Brexit warnings from US and Japan, 4 September 2016 ("Obama tells prime minister US won't prioritise UK trade deal while Tokyo warns of consequences for Japanese businesses" "After her first bilateral meeting with Obama, May was warned that the US wanted to focus on trade negotiations with the EU and a bloc of pacific nations before considering a deal with the UK.").
} 
achieve because it would involve even more States. Some EU Member States also have little interest in concluding a successfull deal with the UK on mutual market access. This is particularly true for financial services where all European financial centres hope to receive their share of the pie if London suffers. The more Brexit uncertainty benefits EU Member States, the longer it will prevail. UK firms should therefore prepare themselves for more than two years of uncertainty. 